\title{
Title: Creation and appropriation of socio-environmental value in coopetition
}

Authors: Jako Volschenk (corresponding author)a

aUniversity of Stellenbosch Business School, P O Box 610, Bellville, 7535, South Africa, Tel: +27 (0)21 918 4234, Fax: +27219184468, Email:

jako.volschenk@usb.ac.za

Marius Ungererb

bUniversity of Stellenbosch Business School, P O Box 610, Bellville, 7535, South Africa, Email: marius.ungerer@usb.ac.za

Eon Smitc

cUniversity of Stellenbosch Business School, P O Box 610, Bellville, 7535, South Africa, Email: Eon.Smit@usb.ac.za 


\section{Author biographies}

Jako Volschenk is a Senior Lecturer in Environmental Finance and Environmental Sustainability at the University of Stellenbosch Business School. He holds a BSc degree, Higher Education Diploma and an MBA. His research interests include environmental coopetition, willingness to pay for green electricity. He has published in journals such as Energy Policy, Applied Energy, Sustainability and the South African Journal of Business Management. He is currently reading for his $\mathrm{PhD}$.

Marius Ungerer is Professor of Strategic Management at the University of Stellenbosch Business School (USB). He previously worked in financial services, manufacturing, information technology, aviation, education and training. Prof Ungerer holds a D.Comm from Rand Afrikaans University. He has published in journals such as International Business Review, Southern African Business Review, African Journal of Business Management, the South African Journal of Industrial Psychology and Sustainability.

Eon Smit is Emeritus Professor and previous Director of the University of Stellenbosch Business School. He holds a D.Comm. degree from the University of Stellenbosch. He is editor of the Journal for Studies in Economics and Econometrics and the South African Journal of Business Management. His research interests include management education, business cycle analysis and financial market phenomena. 


\section{Research highlights}

- We expand the coopetition literature by extending the description of different types of value that is created in coopetition.

- Coopetition to address environmental issues often creates socio-environmental value. Socio-environmental value is a public good and can therefore not be captured by the coopeting parties.

- We present the Coopetition Value Matrix (CVM) as a diagnostic typology. The CVM assists in articulating the creation and appropriation of value in coopetition initiatives, as well as allow a better understanding of the dynamics between different manifestations of value.

- We present an overview of different dynamics between different types of value, and present three broad types of value dynamics. 


\begin{abstract}
Although much has been written about value in coopetition initiatives, the dynamics of value creation and appropriation remain poorly articulated. This paper explores the types of value and the dynamics of value creation and appropriation when competitors cooperate.

The research provides some suggestions towards semantic clarity and introduces new dimensions to the existing value creation and appropriation literature. We also present the Coopetition Value Matrix (CVM), an expanded typology that aids in the understanding of value dynamics in coopetition. Constructing the CVM required the incorporation of stakeholder theory and the concept of socio-environmental value, two aspects that are underexplored in coopetition research.

We applied the CVM to a case of environmental coopetition in the South African wine industry, which provided us with empirical illustrations of the dynamic interaction of different types of value.
\end{abstract}

\title{
Keywords
}

Value creation, Value appropriation, Socio-environmental value, Coopetition Value Matrix, Environmental coopetition, 


\section{Introduction}

A well-used analogy in coopetition literature is that of the enlargement of the value-pie versus the slicing of the pie (Brandenburger \& Nalebuff 1996, Lado, Boyd \& Hanlon 1997, Walley 2007, Chin, Chan \& Lam 2008, Rusko 2011, Ritala, \& Tidström 2014). While this analogy may be powerful at a very high level, it lacks the finesse to articulate value-related dynamics (Garcia-Castro \& Aguilera 2014) in coopetitive initiatives. It is important to understand how value is created and distributed, as this impacts the stability of the coopetition relationship (Kogut 1985, Inkpen \& Beamish 1997, Janssen, de Man \& Quak 2013).

Research on the value aspect of coopetition is still limited, both at theoretical and empirical levels (Ritala \& Tidström 2014). As such, our understanding is impeded by incomplete conceptualisation and measurement of value and by inadequate characterisation of the different dynamics of stakeholder value appropriation (Garcia-Castro \& Aguilera 2014).

Furthermore, while there is sufficient literature about value appropriation in the coopetition body of knowledge (see Dagnino \& Padula 2002, Ritala \& Hurmelinna-Laukkanen 2009, Ritala \& Tidström 2014, Park, Srivastava \& Gnyawali 2014), these typically do not consider a wider stakeholder view of value.

One setting that provides a rich context for understanding value dynamics is environmental coopetition, i.e. when companies collaborate with their competitors to reduce harmful environmental impact or to create environmental value. While a few authors (Steinmo \& Jakobsen 2013, Holmburg \& Örne 2013, De Marchi 2012, Balnco, Lozano \& Rey-Maquieira 2009, Limoubpratum, Shee \& Ahsan 2014) have focused on coopetition to address environmental issues, such cases remain poorly explored.

This paper contributes to the need for a better understanding and articulation of value creation and appropriation dynamics (Garcia-Castro \& Aguilera 2014, Ritala \& Tidström 2014, Park et al. 2014) by addressing two parallel research questions: firstly what types of value companies create and appropriate in environmental coopetition, and secondly how the different types of value interact (i.e. value dynamics) in environmental coopetition. In addressing these two questions, we contribute to the extant literature in five ways.

Firstly we argue for the inclusion of socio-environmental value in the value creation view of coopetition. This aspect extends and consolidates work done by Lado et al. (1997), Dagnino 
and Padula, (2002, 2007), Ritala and Hurmelinna-Laukkanen, (2009), Zhang and Frasier (2011) and Kenworthy (1995).

The main focus in extant coopetion literature has been on common and private benefits as value captured between and within coopeting firms (Ritala \& Tidström 2014). We extend the concept of captured value by introducing a wider stakeholder view (Freeman 1984, Harrison \& Wicks 2013, Hörisch, Freeman \& Schaltegger 2014) of value appropriation (Dyer et al. 2008, Lado et al. 1997, Ritala \& Tidström 2014).

The Coopetition Value Matrix (CVM) represents a third contribution by integrating the expanded perspectives of value. The CVM serves as a typology through which coopetitionrelated value can be mapped and through which value dynamics (Ritala \& Tidström 2014, Garcia-Castro \& Aguilera 2014) can be articulated.

Our fourth contribution is a description of different value dynamics in the CVM. We show an extensive number of observed dynamics, but ultimately we narrow these down to three generic dynamics that inform future studies.

While the above theoretical contributions are potentially generic to most coopetition initiatives, the paper also addresses the call for new empirical contributions (Ritala \& Tidström 2014) by focusing on a case of environmental coopetition. Given the scarcity of coopetition studies in an environmental context, we believe the empirical setting offers an interesting addition to the literature while providing a rich setting to illustrate the proposed theory.

\section{Value dynamics in coopetitive activities}

Coopetition refers to cooperation between competitors (Bengtsson \& Kock 2000: 411). Cooperating with competitors is very different to cooperating with other stakeholders (Ritala 2009) as competitors face similar problems in the market and are likely to depend on similar resources to address such problems (Ritala \& Hurmelinna-Laukkanen 2009). For that reason the knowledge that competitors gain from each other is highly relevant to them (Park Srivastava, \& Gnyawali 2014).

\subsection{Value creation}

When competing firms cooperate, firms are able to combine idiosyncratic, as well as complementary strengths to gain strategic value (Ritala, \& Tidström 2014, Barney 1991). In essence, the value or benefit created in collaborative relationships has been described as value 
that cannot be generated by a firm in isolation and can only be generated through the joint idiosyncratic contributions of the specific alliance partners (Dyer \& Singh 1998: 662).

Dagnino and Padula (2002: 32) elaborated on the work of Kenworthy (1995) to show that coopetitive relationships generate knowledge value in addition to economic value.

Knowledge value is defined as the growth in the interfirm knowledge stock that can be linked to the coopetitive relationship (Dagnino \& Padula 2002: 18-19, 2007: 42) and is arguably less tangible than economic value. However, if this knowledge is applied appropriately, it ultimately translates into economic value (Dagnino \& Padula 2007: 42).

We suggest that coopetition can also create socio-environmental value. The term socioenvironmental value is closely comparable, but not limited, to the value provided through eco-system services (Alcamo \& Bennett 2003) and Total Economic Value (Pearce \& Moran 1994). Table 1 disaggregates different classifications of value into sub-categories.

Place Table 1 here

Socio-environmental value includes both anthropocentric (Hattingh 2009) and intrinsic value (Rolston 1986), but excludes value companies capture as common or private benefit (i.e. rivalrous value). Socio-environmental benefits as used in this paper are thus best described as the sum of intrinsic ecological value and benefits that accrue to society because of environmental improvements.

By implication, all socio-environmental value is public, but not all public goods are socioenvironmental in nature and therefore represent value not available to companies to capture. For instance, when firms share a logistics-network, it may reduce carbon dioxide emissions as well as the cost of road maintenance. The benefit of reduced carbon dioxide emissions is both a socio-environmental benefit and a public good, while the reduced cost of road maintenance is a public good but not a socio-environmental benefit.

\subsection{Value appropriation}

Firms in coopetition have to contend with coopetition partners with opposing objectives who also want to win at the other's expense (Raza-Ullah et al. 2014, Ritala 2009, Ritala \& Tidström 2014, Zhang, Shu, Jiang \& Malter 2010, Park et al. 2014). Value appropriation is firstly concerned with the distribution of common value to the partners, but also considers the ability of partners to generate private benefits (Janssen et al. 2013: 2). It is unclear why 
certain firms manage to capture more of the common value than their partners (Dyer et al. 2008: 137), and the language linked to the concept of common value is inadequate in describing this value (to paraphrase Ritala \& Tidström 2014 and Garcia-Castro \& Aguilera 2014). The existing literature on value appropriation requires clarification on at least two points.

The need for clarification firstly stems from the fact that the creation and appropriation of value are inseparable from each other (Garcia-Castro \& Aguilera 2014) - the total pie is equal to the sum of the slices, which is also true for the increase in the pie. It has been argued, for instance, that the total benefit that can be generated through coopetition is the sum of common benefits and private benefits (Ritala \& Tidström 2014, Dyer et al. 2008). Whereas this definition refers to the generation of benefits, common and private benefits denote the appropriation of benefits.

Secondly, some confusion arises from the definition used for common benefits. Common benefits refer to the collective value generated by the collaborating parties (Khanna, Gulati \& Nohria 1998: 194, Janssen et al. 2013: 2, Ritala \& Tidström 2014). In line with this view Khanna et al. (1998: 194), in one instance, define common benefits as benefits that accrue collectively to all participants in the alliance (from activities in markets that are governed by the alliance). But elsewhere the same authors (Ibid.) describe common benefits as those benefits "that accrue to each partner in an alliance from the collective application of the learning that both firms go through as a consequence of being part of the alliance”. The term common benefit is therefore used to describe both the total value available to coopetitors (the total value created), as well as the individual component that may accrue to a particular firm (the component of the value appropriated).

There is more clarity about the definition of private benefits. Private benefits are those that a firm can capture unilaterally through acquiring knowledge or resources from its partner and applying them elsewhere (Khanna et al. 1998, Dyer et al. 2008: 138, Ritala \& Tidström 2014, Dagnino \& Padula 2007: 42, Park et al. 2014). Private benefits can be generated in either zero-sum or positive-sum logic (Rai 2013). Thus, sometimes the value generated by a firm is at the expense of another, but this is not always the case.

In the interest of semantic clarity, we define three levels of appropriation of benefits, namely common benefits, privately captured common benefits and private benefits (see Table 2).

Table 2 also provides three empirical contexts to illustrate how the proposed definitions 
manifest. The first example (1a-c) illustrates the appropriation of economic value (increased revenue) in the luxury hotel industry (1a-c). The second example illustrates the distribution of economic benefits (cost saving) from a shared logistics network between furniture companies (2a-c). The third example relates to the appropriation of knowledge value from joint research and development in the auto industry (3a-c). We use the columns to indicate whether value appropriation occurs in positive or zero sum logic.

Place Table 2 here

The introduction of privately captured common benefits into the terminology of value resolves some of the ambiguity mentioned previously. The sum of privately captured common benefits would add up to the total common benefit. However, this classification is particularly useful to describe the total benefit captured by a firm, i.e. the sum of privately captured common benefit and private benefit for the particular firm.

But we propose that value appropriation should also consider public benefit. Ignoring the wider implications of coopetitive actions is sub-optimal (Freeman 1984, Bosse, Phillips, \& Harrison 2009, Harrison \& Wicks 2013) as it could potentially destroy or create value for society and for the companies. The question of how much value is created should therefore be accompanied by for whom value is created. Stakeholder theory provides a useful framework to assess the appropriation of value in coopetition initiatives.

The importance of stakeholders can be measured by four attributes (Mitchell, Agle \& Wood 1997, Driscoll \& Starik 2004, Hill \& Jones 1992: 133), namely power, legitimacy, urgency and proximity. Ironically, stakeholder literature considers neither the natural environment, nor competitors in much detail (Driscoll \& Starik 2004, Whysall 2000: 307, Ambler \& Wilson 1995: 4, Clarkson 1995: 99).

The four dimensions of stakeholder importance (power, legitimacy, urgency and proximity) are arguably more visible in environmental coopetition than in environmental initiatives between non-competitors and in non-environmental projects. Environmental coopetition therefore provides an ideal context for exploring the dynamics of value relative to what extant coopetition literature has considered thus far.

\subsection{The coopetition value matrix}


Combining the views of value creation and appropriation into a single typology enables the conceptual disaggregation of value. The Coopetition Value Matrix or CVM (Table 3)

addresses a gap in coopetition literature as identified by Garcia-Castro and Aguilera (2014) and Ritala and Tidström (2014) by:

- improving the articulation of value creation,

- improving the articulation of value appropriation,

- allowing a better understanding of the dynamics of the two processes,

- allowing a better understanding of how different manifestations of value interact,

- allowing the articulation of potential opportunities for increased value creation or appropriation.

Place Table 3 here

From the definition of socio-environmental value it follows that it cannot be captured by coopetitors. However, common or private value can be generated in addition to socioenvironmental value without diminishing it (i.e. it is a positive-sum).

\section{Methodology}

The empirical component of this paper not only served to illustrate the proposed theory, but also illustrated its usefulness in identifying different patterns of value dynamics. We chose a case study approach for a number of reasons. Firstly, case study research is essential in the early development stage of a field (Yin 1981, Ridder, Hoon \& McCandless 2015: 142). When the existing literature is not sufficiently developed to allow for explicit hypotheses, as is the case with the theory we propose, a quantitative study is inappropriate (Edmondson \& McManus 2007, Eisenhardt 1989).

Secondly, seeing how theory manifests in a real-life context makes it more accessible and understandable while allowing for more nuanced knowledge development than what is possible given the tight focus required by quantitative studies (Yin 1981).

Thirdly, case study research is required when the boundaries between the phenomenon and the context is not clear (Yin 1981). Deductive research tends to aggregate a phenomenon without considering different contexts. We needed to see how the intricacies of the case impacted the presence of different types of value and the dynamics of value. 
There is no list of coopetition cases in the wine industry of South Africa. And because the phenomenon is unknown to most respondents, one would not be able to perform an industrywide survey to arrive at such a list. Studies that focus on emergent theory (such as the theory proposed in this paper) often suggest tentative answers of how and why, and also suggest new connections between phenomena (Edmondson \& McManus 2007). The focus was therefore on understanding value and value dynamics rather than on quantifying it (see Bonoma 1985).

\subsection{The case study}

In order to provide an illustration of the value and potential of the CVM at an empirical level, we deliberately focused on one example of environmental coopetition in the South African wine industry, namely The Glass Recycling Company (TGRC). We chose the case to illustrate the proposed theory to its full extent (see Ritala \& Tidström 2014, Eisenhardt 1989 for similar examples). By illustrating the theory, the study aimed to shift consensus rather than create consensus (see Hollenbeck 2008).

TGRC was established in 2006 as a national non-profit organisation. The primary mandate of the TGRC is to "educate, enable, encourage and inspire individuals to separate their glass for recycling” but it does not physically collect or recycle the glass (www.tgrc.co.za).

Although the focus of the study was on competing wine producing entities, the TGRC is an example of collaboration between multiple players, including government, glass manufacturers and glass users. All major stakeholders of glass in the South African beverage industry (wine, beer, spirits and non-alcoholic drinks) are requested to contribute financially to the activities of the TGRC in proportion to the tons of glass they use. Most big players contribute, but payment remains voluntary.

A few large users of glass have permanent seats on the board of TGRC, while smaller wine producers are represented by rotating seats on the board. Collaboration therefore happens via an industry body to which all players contribute financially, and which is jointly governed by stakeholders.

Distell, one of the bigger partners in TGRC, was a focal point for this particular case. Distell operates in a number of alcoholic beverage markets, including wine, spirits (brandy, whiskey, etc.) and "ready to drink" markets. None of the other companies in the wine industry is as diversified. It is also the only company that operates in the wine industry that makes use of 
reusable bottles, albeit in its "ready to drink" and to a lesser extent it's spirit and wine divisions.

\subsection{Data collection and analysis}

We conducted six in-depth interviews as indicated in Table 4. For two of the coopeting companies, respectively, two individuals were interviewed. The remaining two interviews were with an executive member of TGRC and a manager at a much smaller participating company.

Place Table 4 here

Interviewees were asked to provide instances of where they collaborate with competitors to address environmental issues, as well as their perceptions of the value that such initiatives create for the focal firm, the environment, society and competitors.

The interviews were analysed and coded (Saldaña 2010) using ATLAS.ti, a Computer Aided Qualitative Data Analysis Software package. Initial coding was based on themes from the literature, but new codes emerged when the existing constructs were insufficient to describe the data. As often is the case with such studies, data collection, coding and theorising (Edmondson \& McManus 2007: 1158) happened concurrently.

\section{Findings}

\subsection{Types of Value}

Table 5 represents the value matrix of TGRC as reflected in the interviews and other evidence. The CVM allows the visual disaggregation of value in terms of the kind of value, and to whom the value is appropriated. The TGRC matrix shows stronger evidence of economic value and less of knowledge value. As such one could argue that the economic value is the main driver for coopeting parties. At the same time, based on the lack of evidence of knowledge value at the firm level, coopeting parties can consider how more knowledge value could be created in the initiative.

Place Table 5 here 
Distell captures more of the value generated from the initiative than other members. It firstly captures a bigger share of savings than many other players (privately captured common economic benefit) because of the quantity of glass it buys. Because of the size of its financial contribution to TGRC, Distell enjoys board membership. Board membership allows Distell greater reputation protection through its logo on the TGRC website (privately captured common economic benefit), and easier access to information and knowledge (privately captured common knowledge benefit).

\subsection{Value dynamics}

The second research question related to the dynamic interaction between different types of value. The case of TGRC provided some insight into typical dynamics of value in the CVM. As mentioned before, we intentionally chose a case in which multiple types of value were present.

Figures 1 to 3 portray generic patterns of value transfer/appropriation in coopetition initiatives. Figure 1 portrays dynamics of value between the economic and knowledge value classifications. Figure 2 and Figure 3 show the interaction of socio-environmental value with respectively economic value and knowledge value at different levels of appropriation. The figures also provide selected manifestations of these dynamics in the TGRC case.

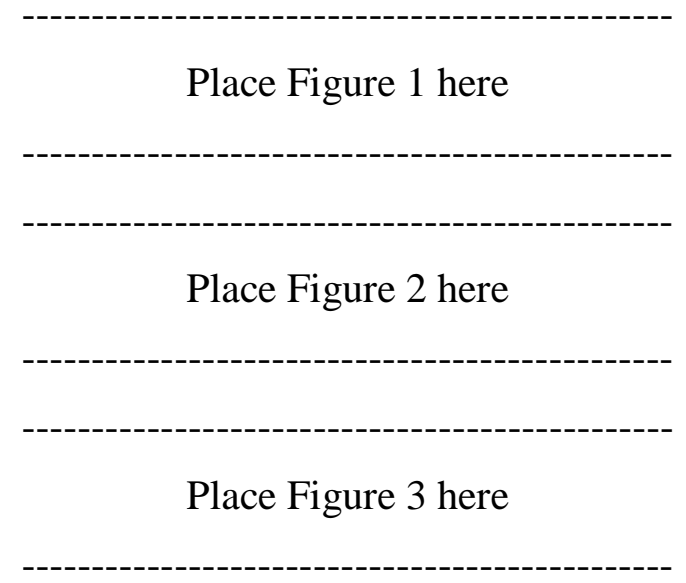

Based on the dynamics in Figures 1 to 3, the case study and the earlier literature review, we identified three ways by which actions drive the creation, appropriation and transference of value:

1. Action as the cause of value 
Value can be created from an action without being linked to any other type of value (cell) in the CVM. For example, when firms cooperate to jointly market a destination, all firms save on marketing expenses, independent of the existence of prior value. But this dynamic can also be true for more types of value that flow from a single action. Two or more types of value may increase simultaneously because of an action, but without being relationally linked to each other. For instance cost savings (economic value) for wine producers, as well as socio-environmental value, increase when society recycles. Both types of value increase because of the recycling action, but the saving is not related to socio-environmental value or vice versa.

\section{Action as the link between different types of value}

Two or more types of value may be causally linked, but requires an action to unlock the dependent value. For example, socio-environmental value affords the coopeting parties the opportunity to realise some brand value. In order for the brand value to be realised, the initiative must be marketed. The economic value is therefore causally linked to the socio-environmental value, but via an action. In cases where causality flows both ways, it creates a reinforcing loop.

\section{Action-independent value}

But value can also flow from another type of value without a direct initiating action. Ecosystem services would be such an example. As an eco-system recovers (i.e. socioenvironmental value increases), the value of eco-system services it provides (common value or socio-economic value) increases without requiring an action.

\section{Discussion and implications}

Garcia-Castro and Aguilera (2014) stress that our understanding of value in coopetition is "impeded by an incomplete conceptualisation and measurement of value and by scant characterisation of the different patterns of stakeholder value appropriation." Similarly, Ritala and Tidström (2014) call for research dealing with value creation and appropriation at both the empirical and theoretical level. This is where our paper fits in with its particular focus on the context of coopetition that generates socio-environmental value. Based on a preconceived conceptual typology, or Coopetition Value Matrix, we investigated the types of value that could potentially be created in coopetition initiatives, as well as how different types of value interact. We chose an environmental initiative in the South African wine 
industry as the context. We empirically illustrate the theoretical framework by populating the matrix and showing how value of different types may interact.

\subsection{Contributions and research implications}

This study relies on previous works (Dagnino \& Padula 2002, Dyer \& Singh 1998, GarciaCastro \& Aguilera 2014, Ritala \& Tidström 2014, Lado et al. 1997, Park, Srivastava \& Gnyawali 2014) and extends our understanding of value and its dynamics at a conceptual and empirical level. We believe our paper makes conceptual contributions at four levels.

We firstly contribute to the coopetition literature by extending the descriptions of the types of value at the creation level. We argue that coopetition may create socio-environmental value in some instances. Although socio-environmental value is a public benefit and therefore cannot be appropriated to coopeting parties, it can act as a catalyst to creating value for the coopeting firms.

Our second contribution is to incorporate stakeholder theory into the value appropriation view as presented by authors such as Dyer et al. (2008), Lado et al. (1997) and Ritala and Tidström (2014). Coopetition literature has previously focused mostly on the value that can be created for the partner firms. We suggest that studies of value in coopetition initiatives should consider the value that is created (or destroyed) for society, particularly because such value could create an incentive for society to support the coopetition objectives.

Our third contribution relates to how different types of value may interact. The Coopetition Value Matrix (CVM) integrates the broader value creation-appropriation views and serves as a typology by which value dynamics (Ritala \& Tidström 2014, Garcia-Castro \& Aguilera 2014) can be articulated. Different types of value, and value at different levels of appropriation, can be associated conceptually with value in other parts of the CVM.

Our fourth contribution relates to the call for a better understanding of value dynamics. We believe the articulation of value dynamics presented in this paper provides strong insights for future research and that the CVM is a powerful tool for both a conceptual and empirical discourse about value in coopetition initiatives. We also present three broad types of dynamics between different types of value.

While each instance of coopetition may be different in the specific nature of the types of value, the dynamics in the CVM can be considered as generic. We do not claim to have identified all the potential dynamics, but the matrix and the dynamics we identify provide a 
robust point of reference for future studies, particularly studies that recognise a wider stakeholder view of value.

\subsection{Implications for managers}

The actions of coopetition parties could have both negative and positive impacts for other stakeholders, and not considering such impacts is sub-optimal. Apart from the private and common benefits that companies could capture from environmental coopetition initiatives, they should also take heed of value that can be created for society. This value is nonexcludable and hence there is little direct economic benefit for companies to participate from a strictly financial point of view.

However, as was shown in the study, it is possible to generate economic value from environmental coopetition initiatives by, for example, actively raising awareness in the market about the initiative. This implies that some initiatives should happen in close proximity to customers in order to unlock value for the coopeting partners. Understanding how to use the potential exposure is key to capturing common benefit and generating private benefit from the public value that is created. More generally, to exploit opportunities for value creation for the partners or for a focal firm, requires competencies that we referred to as actions earlier in the paper. Firms that are better at learning will be better equipped to create and capture value.

By mapping coopetition initiatives in the coopetition value matrix, managers can be sensitised about the possibility of maximising stakeholder value while also identifying missed opportunities.

It is possible that socio-environmental value and other forms of public benefit are unintended consequences, or just not deliberate consequences, of coopetition initiatives. Once managers are aware of the value that they create for society through their coopetitive actions, it may become valuable, and ultimately deliberate.

\subsection{Limitations and the agenda for future research}

The most obvious limitations of this paper are that it was conducted in one industry (i.e. the wine industry) and that it studied a particular special case of coopetition i.e. coopetition to address environmental issues. We do believe that the dynamics of value portrayed in this paper would hold in other contexts as well, but further research is required to corroborate the conceptual contribution of this study. 
The South African wine industry is highly fragmented (i.e. competition levels seem to be low), and therefore one would not necessarily expect firms in other industries to act in the same way. It is therefore likely that other contexts may result in other manifestations of the different types of value to those we present. For instance, firms in the fishing, forestry or mining industries would benefit from the expanded view of value in coopetition as presented in this paper, but may present other types of environmental coopetition and could potentially exhibit different value dynamics. Research on why certain patterns emerge would be valuable, as well as how particular patterns in the CVM impact the stability of coopetition initiatives.

The CVM represents a qualitative view of value in coopetition initiatives. There would certainly be merit in conducting large sample deductive studies in order to explore quantitatively the dynamics illustrated in this study.

By implication, we foresee that the coopetitive framework proposed here may be extended in the future to a range of analytical levels referring to relationships between other market, nonmarket or extramarket institutions such as governments, interest groups, unions and firms and among countries and blocks of countries. ${ }^{1}$

Note: This work forms part of a larger PhD study. We wish to thank the reviewers at the 6th Workshop on Coopetition Strategy: "Coopetition Strategy and Practice" in Umeå, Sweden (2014) for their valuable questions and contributions. We would further like to thank the editor of this special issue and three blind reviewers for the very helpful comments and suggestions to improve this paper.

\footnotetext{
${ }^{1}$ Our thanks to a blind reviewer for this suggestion.
} 


\section{References}

Alcamo, J., \& Bennett, E. (2003). Ecosystems and human well-being: a framework for assessment. Island Press, Washington.

Ambler, T. and Wilson, A. 1995. Problems of stakeholder theory. Business Ethics: A European Review, 4(1), 30-35.

Barney, J. (1991). Firm resources and sustained competitive advantage. Journal of Management, 17(1), 99-120.

Bengtsson, M., \& Kock, S. (2000). Coopetition in business networks - to cooperate and compete simultaneously. Industrial Marketing Management, 29(5), 411- 426.

Bengtsson, M., \& Kock, S. (2014). Coopetition-Quo vadis? Past accomplishments and future challenges. Industrial Marketing Management, 43(2), 180-188

Bonoma, T. (1985). Case research in marketing: opportunities problems, and a process. Journal of Marketing Research, 22(000002), 199-208

Bosse, D. A., Phillips, R. A., \& Harrison, J.S. (2009). Stakeholders, reciprocity and firm performance. Strategic Management Journal, 30(4), 447-56.

Bowman, C., \& Ambrosini, V. (2000). Value creation versus value capture: towards a coherent definition of value in strategy. British Journal of Management, 11(1), 1-15 Brandenburger, A.M., Nalebuff, B.J. (1996). Co-opetition. Doubleday: New York. Czakon, W., Mucha-Kus, K., Rogalski, M. (2014). Coopetition research landscape - A systematic literature review 1997-2010. Journal of Economics \& Management, 17, 121-150 Dagnino, G., \& Padula, G. (2002). Coopetition strategy: A new kind of interfirm dynamic for value creation. Paper presented at The European Academy of Management second annual conference, 9-11 May 2002.

Dagnino, G.B., \& Padula, G. (2007). Untangling the rise of coopetition: the intrusion of competition in a cooperative game structure. International Studies of Management and Organization, 37(2), 32-52.

De Marchi, V. (2012). Environmental innovation and R\&D cooperation: empirical evidence from Spanish manufacturing firms. Research Policy, 41(3), 614-623 
Driscoll, C., \& Starik, M. (2004). The primordial stakeholder: advancing the conceptual consideration of stakeholder status for the natural environment. Journal of Business Ethics, 49(1), 55-73

Dyer, J.H., \& Singh, H. (1998). The relational view: cooperative strategy and sources of inter-organizational competitive advantage. Academy of Management Review, 23(4), 660679.

Dyer, J.H., Singh, H., \& Kale, P. (2008). Splitting the pie: rent distribution in alliances and networks. Managerial and Decision Economics, 29(2-3), 137-148

Edmondson, A.C., \& McManus, S.C. (2007). Methodological fit in management field research. Academy of Management Review, 32(4), 1155-1179

Eisenhardt, K.M. (1989). Building theories from case study research. The Academy of Management Review, 14(4), 532-550.

Freeman, E.R. (1984). Strategic management: a stakeholder approach. Pitman/Ballinger: Boston, MA

Garcia-Castro, R., \& Aguilera, R. (2014). Incremental value creation and appropriation in a world with multiple stakeholders. Strategic Management Journal, DOI: 10.1002/smj.2241

Harrison, J., \& Wicks, A. (2013). Stakeholder theory, value, and firm performance. Business Ethics Quarterly, 23(1), 97-124

Hardin, G. (1968). The tragedy of the commons, Science, 162, 1243-1248

Hatting, J. (2009). Environmental ethics. climate change and arctic sustainable development: Scientific, social, cultural and educational challenges. UNESCO International Experts Meeting, 3-6 March 2009, Monaco. [online] Available at: http://www.unesco.org/ csi/LINKS/monaco-abstracts/Hattingh_Keynote_abstract_MonacoUNESCOarctic.pdf Downloaded on 10 October 2014

Hill, C.W.L., \& Jones, T.M. (1992). Stakeholder-agency theory. Journal of Management Studies, 29(2), 131-154.

Hollenbeck, J.R. (2008). The role of editing in knowledge development: consensus shifting and consensus creation. In Y. Baruch, A.M. Konrad, H. Aguinus, \& W.H. Starbuck (Eds.), Journal editing: opening the black box (pp. 16-26). San Francisco: Jossey Bass. 
Holmburg, A., \& Örne, K. (2013). Starfish coopetition for innovative freight transport solutions in Swedish retail. Master's thesis submitted at Lund University. [online] Available at: http://lup.lub.lu.se/luur/download?func=downloadFile\&recordOId=4250916\&fileOId= 4250939 Downloaded on 25 January 2014

Hörisch, J., Freeman, R.E., \& Schaltegger, S. (2014). Applying stakeholder theory in sustainability management: links, similarities, dissimilarities, and a conceptual framework. Organization \& Environment, 27(4), 328-346

Inkpen, A., \& Beamish, P. (1997). Knowledge, bargaining power, and the instability of international joint ventures. Academy of Management Review, 22: 177-202.

Janssen, G., de Man, A., \& Quak, H. (2013). Fairness and value appropriation in logistics alliances: a case-study approach. Proceedings of the 24th POMS Annual Meeting, Denver, Colorado, USA [online] Available at: http://www.pomsmeetings.org/ConfProceedings/043 /FullPapers/FullPaper_files/043-0632.pdf Downloaded on 25 January 2014

Kenworthy, L. (1995). In search of national economic success. balancing competition and cooperation. Sage: Thousand Oaks (CA)

Khanna, T.R., Gulati, R., \& Nohria, N. (1998). The dynamics of learning alliances: competition, cooperation, and relative scope. Strategic Management Journal, 19(3), 193-210. Kogut, B. (1989). The stability of joint ventures: reciprocity and competitive rivalry. Journal of Industrial Economics, 38(2), 183-198.

Lado, A., Boyd, N., \& Hanlon, S. (1997). Competition, cooperation, and the search for economic rents: a syncretic model. Academy of Management Review, 22(1), 110-141 Lepak, D.P., Smith, K.G., \& Taylor, M.S. (2007). Value creation and value capture: a multilevel perspective. Academy of Management Review, 32(1), 180 -194.

Limoubpratum, C., Shee, H., \& Ahsan, K. (2014). Sustainable distribution through coopetition. International Journal of Logistics Research and Applications: A Leading Journal of Supply Chain Management, DOI: 10.1080/13675567.2014.977236

Mitchell. R., Agle. B., \& Wood. D. (1997). Toward a theory of stakeholder identification and salience: defining the principle of who and what really counts. Academy of Management Review, 22(4), 853-886. 
Ostrom, E. (1990). Governing the commons: the evolution of institutions for collective action. Cambridge University Press

Park, B.-J.R., Srivastava, M.K., \& Gnyawali, D.R. (2014). Walking the tight rope of coopetition: impact of competition and cooperation intensities and balance on firm innovation performance. Industrial Marketing Management, 43(2), 210-221

Pearce, D.W., \& Moran, D. (1994). The economic value of biodiversity. London: EarthScan Rai, R. (2013). A co-opetition-based approach to value creation in interfirm alliances: construction of a measure and examination of its psychometric properties. Journal of Management, DOI: 10.1177/0149206313515525

Raza-Ullah, T., Bengtsson, M., \& Kock, S. (2014). The coopetition paradox and tension in coopetition at multiple levels. Industrial Marketing Management, 43(2), 189-198

Ritala, P. (2009). Is coopetition different from cooperation? The impact of market rivalry on value creation in alliances. International Journal of Intellectual Property Management, 3(1), $39-55$

Ritala, P., \& Hurmelinna-Laukkanen, P. (2009). What's in it for me? Creating and appropriating value in innovation-related coopetition. Technovation, 29, 819-828

Ritala, P., \& Tidström, A. (2014). Untangling the value-creation and value-appropriation elements of coopetition strategy: a longitudinal analysis on the firm and relational levels. Scandinavian Journal of Management, 30, 498-515

Rolston, H. (1986). Philosophy gone wild: essays in environmental ethics. Amherst, NY: Prometheus

Rusko, R. (2011). Exploring the concept of coopetition: a typology for the strategic moves of the Finnish forest industry. Industrial Marketing Management, 40(2), 311 - 320.

Saldaña, J. (2010). The coding manual for qualitative researchers. Sage Publications: London

Steinmo, M., \& Jakobsen, S. (2013). Greening an industry through coopetition: the role of proximity in an $R \& D$ alliance to create environmental innovations. 35th DRUID Celebration Conference 2013, Barcelona, Spain, June 17-19. [online] Available at: http://druid8.sit.aau. dk/acc_papers/b96ih3sjlnsyeu96apnq04skphpy.pdf Downloaded on 9 April 2013 
TGRC. (2012). The glass recycling company: about us. [online] Available at: http://www.theglassrecyclingcompany.co.za/index.php?option=com_content\&view=article\&i $\mathrm{d}=75 \&$ Itemid=49 Downloaded on 21 September 2012

Walley, K. (2007). Coopetition: an introduction to the subject and an agenda for research. International Studies of Management and Organization, 37(2), 11-31

Whysall, P. (2000). Addressing ethical issues in retailing: a stakeholder perspective. The international review of retail, distribution and consumer research. 10(3), 305-318, DOI: $10.1080 / 095939600405992$

Zhang, J., \& Frazier, G. (2011). Strategic alliance via co-opetition supply chain partnership with a competitor. Decision support systems, doi:10.1016/j.dss.2011.02.004

Zhang, H.S., Shu, C.L., Jiang, X., \& Malter, A.J. (2010). Managing knowledge for innovation: the role of cooperation, competition, and alliance nationality. Journal of International Marketing, 18(4), 74-94. 
Table 1: Comparison of value related terminology

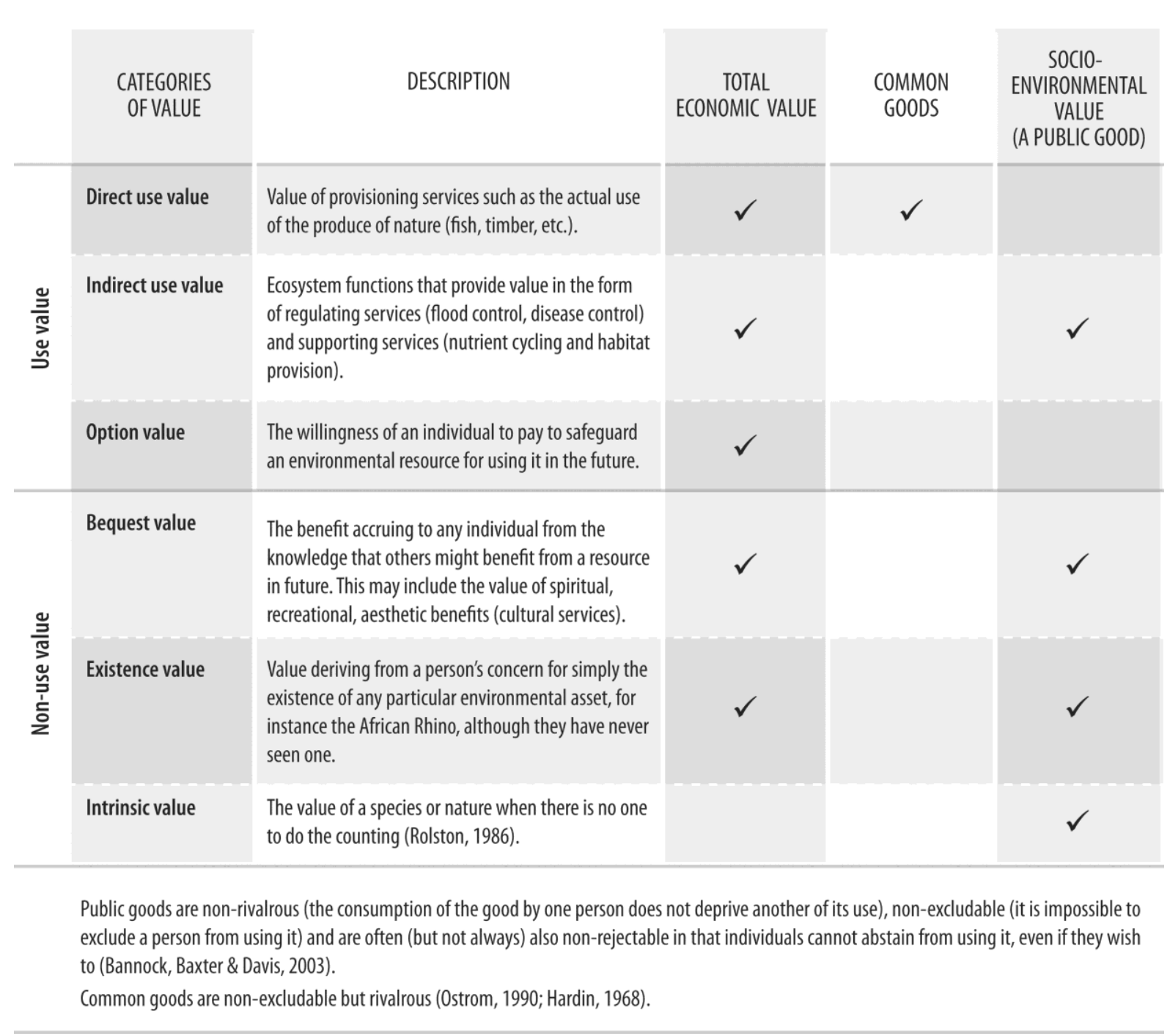

Source: Adapted from Pearce \& Moran (1994); Alcamo \& Bennett (2003); Hattingh (2009); Ostrom (1990); Hardin (1968); (Bannock, Baxter \& Davis, 2003) 


\section{Table 2: A typology of value appropriation}

\begin{tabular}{|c|c|c|}
\hline & POSITIVE-SUM & ZERO-SUM \\
\hline $\begin{array}{l}\text { Common benefit: } \\
\text { Value that is generated as a result of the coopetition } \\
\text { relationship in positive-sum logic (Ritala \& Tidström, } \\
\text { 2014; Park et al., 2014; Rai, 2013), and accrues } \\
\text { collectively to the coopetitors in relation to some } \\
\text { level of contribution in the initiative (Janssen et al., } \\
2013: 2 \text { ). When such value is captured by one } \\
\text { coopetitor, it leads to the second classification, } \\
\text { namely privately captured common benefits. }\end{array}$ & $\begin{array}{l}\text { 1a) The aggregate increase in revenue } \\
\text { generated by competing luxury hotels from } \\
\text { joint destination marketing aimed at } \\
\text { attracting more tourists to Cape Town. } \\
\text { 2a) The total cost saving generated from a } \\
\text { joint logistics network in which competing } \\
\text { furniture companies use the same distribu- } \\
\text { tion channel. } \\
\text { 3a) The total intellectual capital generated } \\
\text { from joint R\&D by auto-manufacturers (e.g. } \\
\text { Toyota \& PSA Peugeot Citroen in their } \\
\text { research around city transport). }\end{array}$ & \\
\hline $\begin{array}{l}\text { Privately captured common benefit: } \\
\text { Value that accrues to a particular coopetitor from the } \\
\text { collective value generated in the coopetition } \\
\text { relationship. The process of appropriation of value } \\
\text { can happen in positive-sum or zero-sum logic (Ritala } \\
\text { \&Tidström, 2014). }\end{array}$ & $\begin{array}{l}\text { 2b) The cost reduction enjoyed by a furniture } \\
\text { company as a result of a joint logistics } \\
\text { network. The fact that it may experience a } \\
\text { cost reduction does not prevent its } \\
\text { competitor(s) from enjoying a similar cost } \\
\text { reduction. } \\
\text { 3b) The increase in intellectual capital of a } \\
\text { particular auto manufacturer (e.g. PSA } \\
\text { Peugeot Citroen) generated from joint R\&D. } \\
\text { What it learns from the initiative does not } \\
\text { prevent Toyota from also gaining knowledge } \\
\text { and both may gain the same knowledge. }\end{array}$ & $\begin{array}{l}\text { 1b) The revenue accruing to a particular } \\
\text { luxury hotel in Cape Town as a result of joint } \\
\text { destination marketing (with other luxury } \\
\text { hotels). Each tourist it attracts means one } \\
\text { less customer for other hotels in Cape Town. }\end{array}$ \\
\hline $\begin{array}{l}\text { Private benefit: } \\
\text { Value that a firm can capture unilaterally through } \\
\text { acquiring knowledge or resources from its partners } \\
\text { and applying it outside the boundaries of the } \\
\text { coopetition initiative (Khanna et al., 1998; Dyer et } \\
\text { al., 2008: 138; Ritala \& Tidström, 2014; Dagnino \& } \\
\text { Padula, 2007: 42; Park et al., 2014). Such value can } \\
\text { be captured in differentiating (positive-sum) logic } \\
\text { (Ritala \& Tidström, 2014) or zero-sum logic (Rai, } \\
\text { 2013). }\end{array}$ & $\begin{array}{l}\text { 2c) The revenue generated by a company } \\
\text { that sells both furniture and interior design } \\
\text { products when it uses a joint distribution } \\
\text { channel with other furniture companies that } \\
\text { do not sell interior design products. } \\
\text { 3c) The value of intellectual capital that an } \\
\text { auto company (PSA Peugeot Citroen) can } \\
\text { apply in its motorcycle plant, while its } \\
\text { competitor (Toyota) does not operate in that } \\
\text { market (and is not able to capture such } \\
\text { value). }\end{array}$ & $\begin{array}{l}\text { 1c) The revenue generated by a luxury hotel } \\
\text { group that is present in Cape Town when it is } \\
\text { able to refer a guest to its branch in Paris } \\
\text { while at least one of its competitors has a } \\
\text { branch there. }\end{array}$ \\
\hline
\end{tabular}




\section{Table 3: Coopetition Value Matrix}

\begin{tabular}{|c|c|c|c|}
\hline & & & \\
\hline & ECONOMIC & KNOWLEDGE & SOCIO-ENVIRONMENTAL \\
\hline \multirow[b]{2}{*}{$\begin{array}{l}\text { 응 } \\
\frac{\cos }{\alpha} \\
\frac{0}{0}\end{array}$} & $\begin{array}{l}\text { Economic value - generated as a result of } \\
\text { the coopetition relationship in positive- } \\
\text { sum logic - in the form of tangible } \\
\text { (increased revenue, lower expenses) or } \\
\text { intangible (increased brand, lower risk) } \\
\text { value. Examples include: } \\
\text { - Joint R\&D investment } \\
\text { - Workforce training investment } \\
\text { - Quicker agreement on standards } \\
\text { - Reduced Time-to-Market } \\
\text { - Joint production }\end{array}$ & $\begin{array}{l}\text { A positive-sum logic increase in the } \\
\text { collective knowledge stock of the } \\
\text { coopetitors as a result of the coopeti- } \\
\text { tion relationship. This could be aspects } \\
\text { related to: } \\
\text { - Industry new knowledge creation } \\
\text { and transfer } \\
\text { - Communication \& information flows } \\
\text { - Co-design } \\
\text { - Co-development }\end{array}$ & \multirow[t]{3}{*}{$\begin{array}{l}\text { A benefit accrues to society because of } \\
\text { environmental improvements, but this } \\
\text { value is non-excludable (i.e. it cannot } \\
\text { be captured by any of the coopetitors } \\
\text { exclusively) and can therefore not be } \\
\text { considered as a common or private } \\
\text { benefit. For this reason this cell is } \\
\text { empty in the CVM. }\end{array}$} \\
\hline & $\begin{array}{l}\text { The component of economic value } \\
\text { captured by any particular firm of the } \\
\text { benefit created within the coopetition } \\
\text { initiative. By implication, the remain- } \\
\text { der of the common value is appropri- } \\
\text { ated to the other participants. The } \\
\text { appropriation can follow either a } \\
\text { positive or zero-sum logic. }\end{array}$ & $\begin{array}{l}\text { A positive-sum logic increase in the } \\
\text { knowledge stock of any particular firm } \\
\text { that relates to the objectives of the } \\
\text { coopetitive initiatives. }\end{array}$ & \\
\hline 崖 & $\begin{array}{l}\text { The economic value generated by a } \\
\text { firm outside of the coopetition } \\
\text { relationship from skills or resources } \\
\text { acquired inside the coopetitive } \\
\text { relationship. The appropriation can } \\
\text { follow either a positive or zero-sum } \\
\text { logic. }\end{array}$ & $\begin{array}{l}\text { A positive-sum logic increase in the } \\
\text { knowledge stock of a firm that has } \\
\text { value outside of the coopetitive } \\
\text { relationship, but based on knowledge } \\
\text { that was acquired inside the coopeti- } \\
\text { tive relationship. }\end{array}$ & \\
\hline $\begin{array}{l}\text { 블 } \\
\stackrel{9}{\partial}\end{array}$ & $\begin{array}{l}\text { Economic value (or socio-economic } \\
\text { value) accruing to society as a result of } \\
\text { the coopetitive relationship. The } \\
\text { appropriation follows positive-sum } \\
\text { logic. }\end{array}$ & $\begin{array}{l}\text { An increase in the knowledge stock in } \\
\text { society as a result of the coopetitive } \\
\text { activities or relationship. The } \\
\text { appropriation follows positive-sum } \\
\text { logic. }\end{array}$ & $\begin{array}{l}\text { An increase in environmental value } \\
\text { expressed as the utility for society, or as } \\
\text { intrinsic value. Such value can derive } \\
\text { from: } \\
\text { - Protecting a species of fauna or flora } \\
\text { - Reducing resource intensity } \\
\text { - Reducing waste } \\
\text { The appropriation follows positive-sum } \\
\text { logic. }\end{array}$ \\
\hline
\end{tabular}


Table 4: Interviewees

\begin{tabular}{|c|c|c|c|c|}
\hline LABEL & DESCRIPTION & POSITION & $\begin{array}{l}\text { DATE OF } \\
\text { INTERVIEW }\end{array}$ & $\begin{array}{l}\text { DURATION OF } \\
\text { INTERVIEW (HRS) }\end{array}$ \\
\hline W2 & $\begin{array}{l}\text { Wine producer, diversified liquor company, medium sized in } \\
\text { bottling capacity. }\end{array}$ & Executive & $8 \mathrm{Jul} 2011$ & $1: 27$ \\
\hline W3 & $\begin{array}{l}\text { Wine producer, diversified liquor company, medium sized in } \\
\text { bottling capacity. }\end{array}$ & Executive & $8 \mathrm{Jul} 2011$ & $1: 27$ \\
\hline W4 & $\begin{array}{l}\text { Wine producer, diversified liquor company, large sized in bottling } \\
\text { capacity. }\end{array}$ & Executive & 13 Jul 2011 & $1: 23$ \\
\hline W5 & $\begin{array}{l}\text { Wine producer, known as a sustainability leader, medium sized in } \\
\text { bottling capacity. }\end{array}$ & Executive & 16 Jul 2012 & 1:17 \\
\hline W9 & $\begin{array}{l}\text { Wine producer, diversified liquor company, large sized in bottling } \\
\text { capacity. Has board representation on TGRC board. }\end{array}$ & Executive & 11 Mar 2014 & $0: 45$ \\
\hline $\mathrm{T} 1$ & Industry body & Executive & 31 Mar 2015 & $0: 52$ \\
\hline
\end{tabular}




\section{Table 5: Coopetition Value Matrix for The Glass Recycling Company}

\begin{tabular}{|c|c|c|c|c|}
\hline & & \multirow[b]{2}{*}{ ECONOMIC } & \multirow{2}{*}{$\begin{array}{l}\text { VALUE CREATION } \\
\text { KNOWLEDGE }\end{array}$} & \multirow[b]{2}{*}{ SOCIO-ENVIRONMENTAL } \\
\hline & & & & \\
\hline \multicolumn{2}{|r|}{ 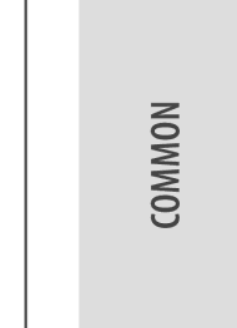 } & $\begin{array}{l}\text { Cullet (broken glass) melts at a lower } \\
\text { temperature, meaning an energy } \\
\text { saving in the glass manufacturing } \\
\text { process. Some of this saving may be } \\
\text { passed on to wine bottlers } \\
\text { (Interviewee W4). } \\
\text { TGRC provides reputation protection to } \\
\text { member firms (Interviewee W9). }\end{array}$ & $\begin{array}{l}\text { TGRC serves as knowledge hub to the } \\
\text { glass industry (Interviewee T1). }\end{array}$ & \multirow[t]{3}{*}{$\begin{array}{l}\text { Socio-environmental value is per } \\
\text { definition value that accrues to society } \\
\text { and a public good. It therefore implies } \\
\text { that it cannot be captured by the } \\
\text { coopetition parties. }\end{array}$} \\
\hline \multirow{3}{*}{ 을 } & 恶峞 员 & $\begin{array}{l}\text { The "reduced cost" benefit captured by } \\
\text { any of the partners is proportional to } \\
\text { the amount of glass they buy } \\
\text { (Interviewee W9). } \\
\text { Larger firms benefit more by having } \\
\text { more representation on the board and } \\
\text { having their brands associated with } \\
\text { TGRC (Interviewee W9). }\end{array}$ & $\begin{array}{l}\text { Representation on the board provides } \\
\text { some players with a higher level of } \\
\text { access to information and knowledge. } \\
\text { (Interviewee } \mathrm{T} 1, \mathrm{~W} 9 \text { ). }\end{array}$ & \\
\hline & 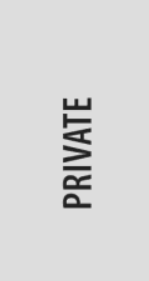 & $\begin{array}{l}\text { TGRC receives contributions from all } \\
\text { glass users. Many glass users } \\
\text { contribute funds. The funds are used to } \\
\text { promote both recycling and reuse of } \\
\text { glass, but only one firm reuses glass in } \\
\text { its "spirits" division (Interviewee W4, } \\
\text { W9). }\end{array}$ & $\begin{array}{l}\text { Distell adopts knowledge that it } \\
\text { gained in its involvement with the } \\
\text { TGRC into areas that its competitors do } \\
\text { not operate. }\end{array}$ & \\
\hline & $\begin{array}{l}\text { 늠 } \\
\text { ํㅗㅁ }\end{array}$ & $\begin{array}{l}\text { Glass is recycled and reused, meaning } \\
\text { reduced cost to society for waste disposal } \\
\text { and landfills (IntervieweeW9,T1). } \\
\text { The bulk of glass recycling is driven by } \\
\text { the lower end of the market who } \\
\text { earns a living from recycling } \\
\text { (Interviewee T1). } \\
\text { The lower cost to the glass manufac- } \\
\text { turer could potentially translate to } \\
\text { lower cost of bottled wine. }\end{array}$ & $\begin{array}{l}\text { The primary mandate of TGRC is to } \\
\text { raise public awareness regarding glass } \\
\text { recycling, glass reuse, and the benefits } \\
\text { thereof (Interviewee T1, TGRC } \\
\text { website). }\end{array}$ & $\begin{array}{l}\text { Recycling glass has numerous benefits } \\
\text { for the environment in terms of a } \\
\text { reduction in pollution and resource } \\
\text { dependency (Glass producer website). }\end{array}$ \\
\hline
\end{tabular}




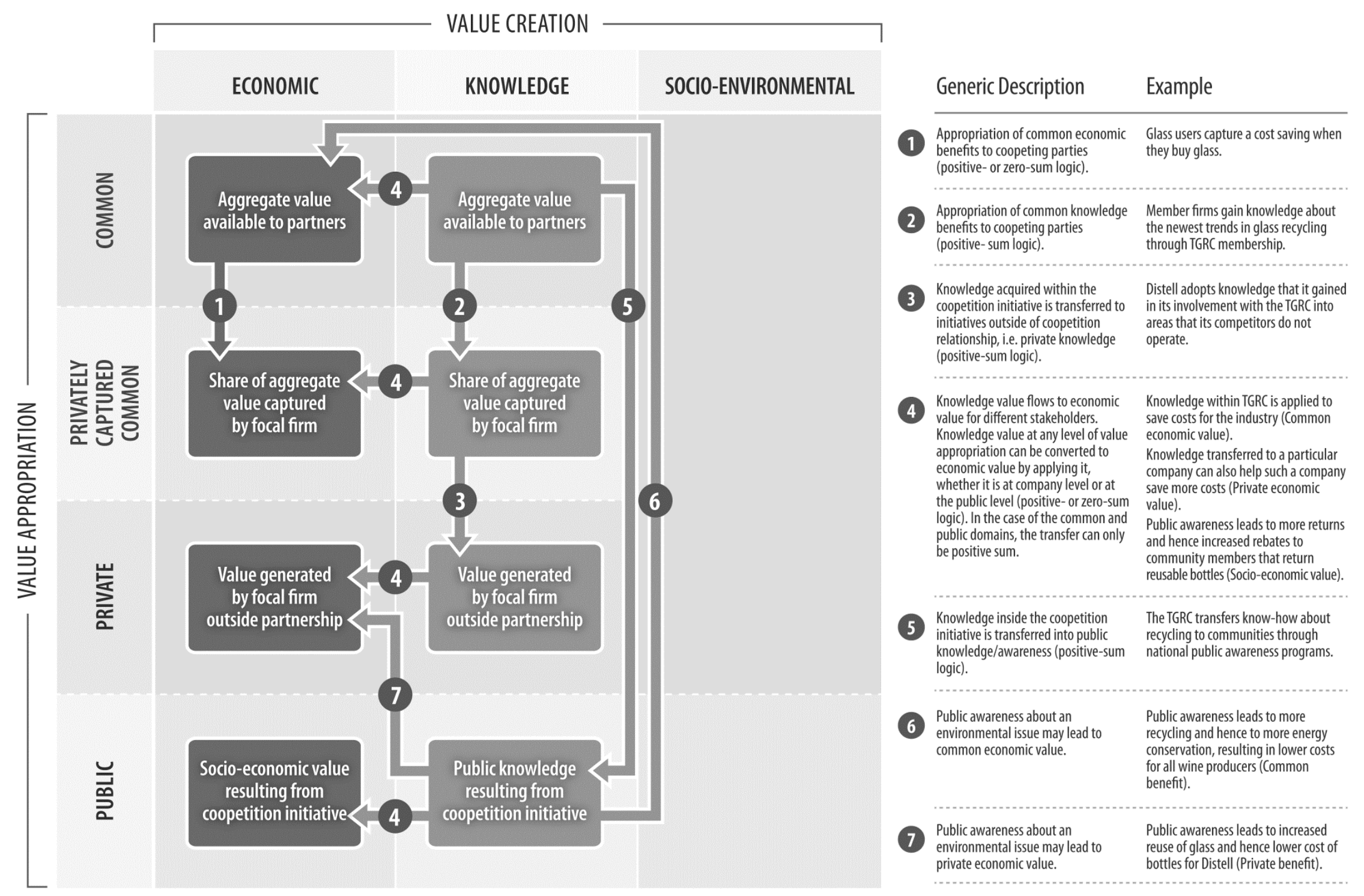

Figure 1: Value dynamics of common economic and knowledge value 


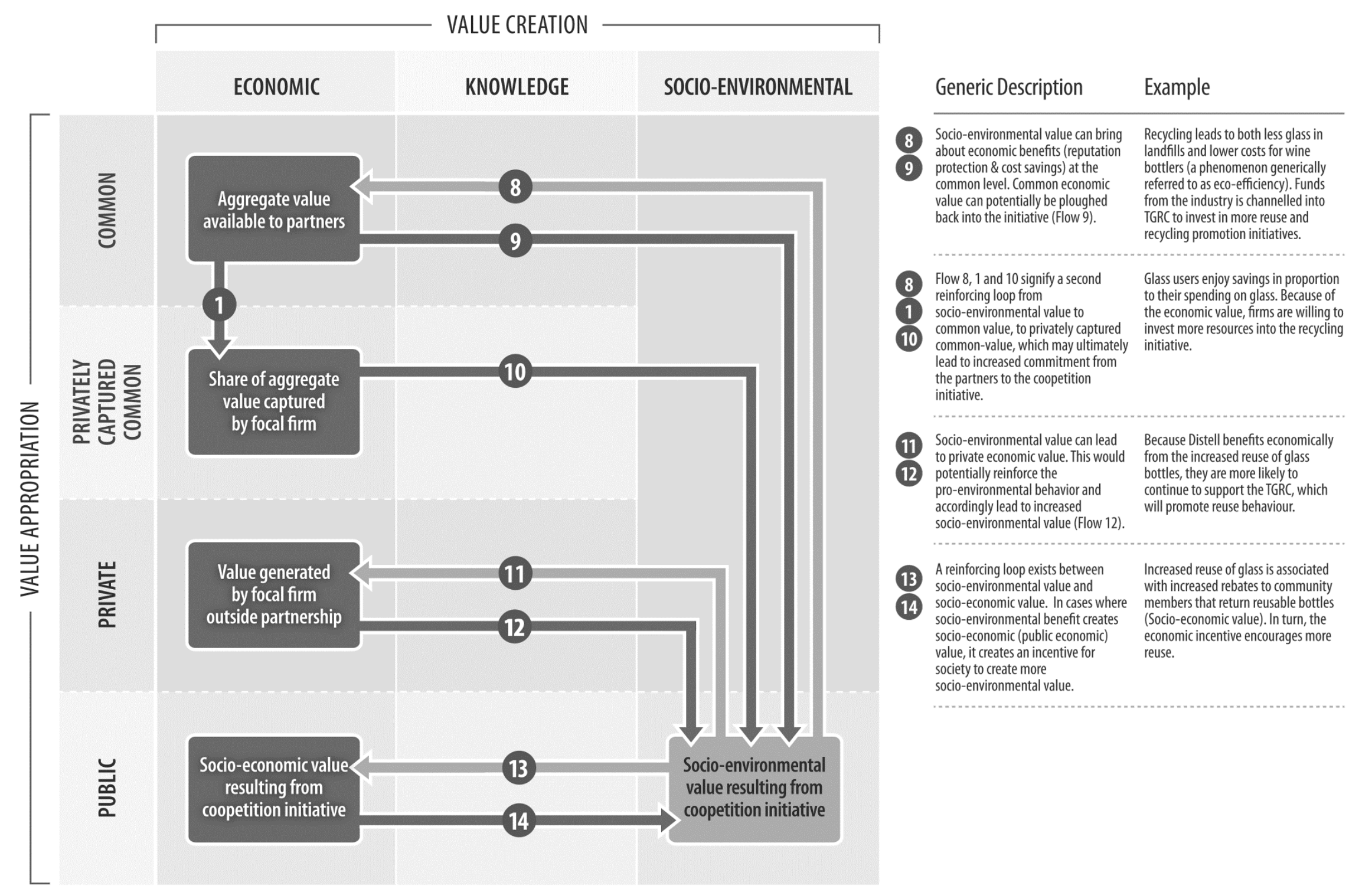

Figure 2: Dynamics of socio-environmental value and economic value 


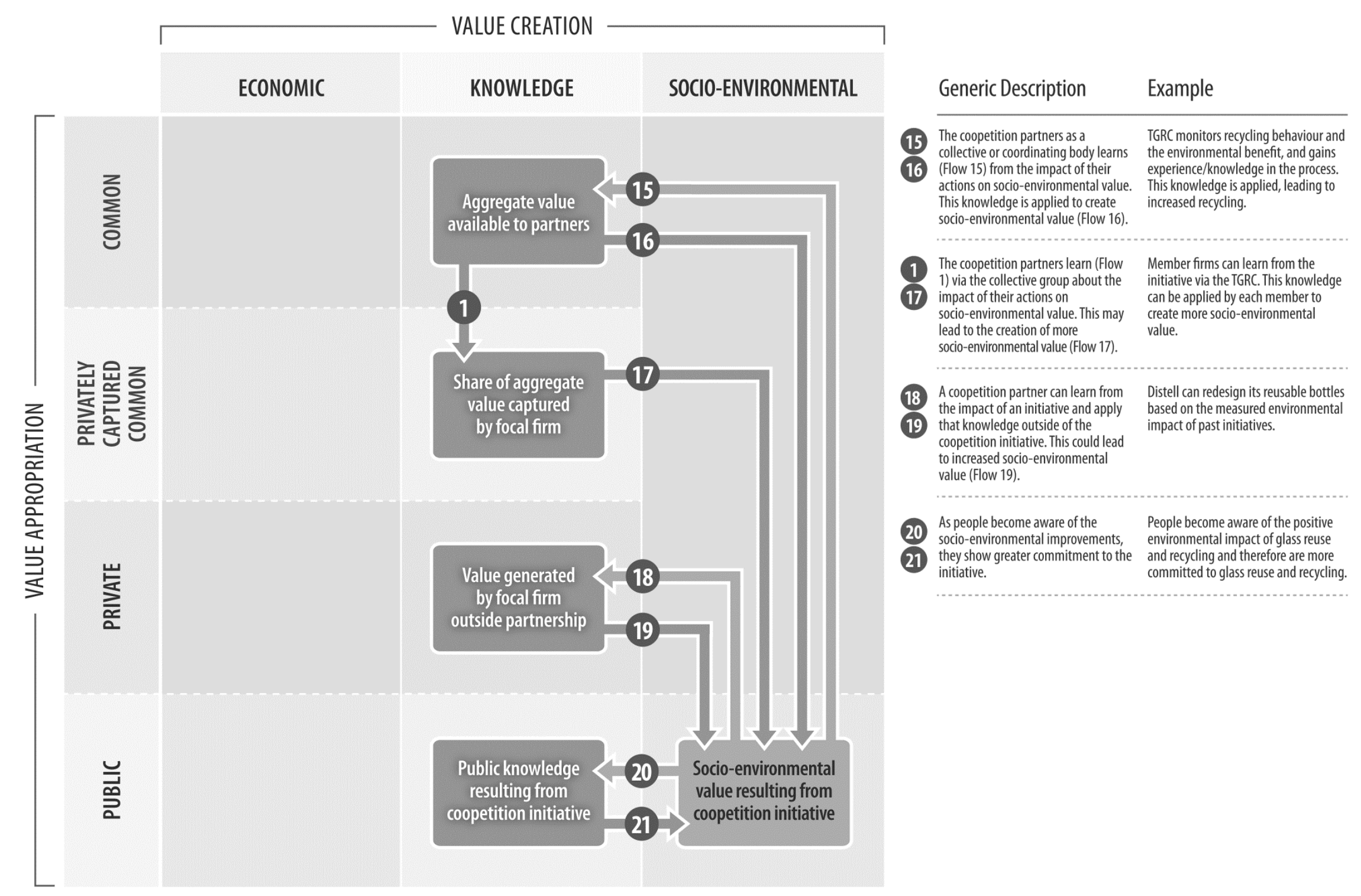

Figure 3: Dynamics of socio-environmental value and knowledge value 